\title{
THE REGULATION OF PUBLIC-PRIVATE PARTNERSHIPS: A COMPARATIVE STUDY OF NIGERIA AND SOUTH AFRICA
}

\author{
Augustine Edobor Arimoro, PhD \\ St Mary's Law School \\ St Mary's University Twickenham London \\ augustine.arimoro@stmarys.ac.uk
}

\begin{abstract}
Budget deficits, economic crisis and competing demands for lean state resources are clear reasons why governments, especially in sub-Saharan Africa are now inclined towards the public-private partnership model of infrastructure finance. This paper comparatively examines the regulation of public-private partnership in Nigeria and South Africa. The aim is to highlight areas where both countries can learn from their experiences. The paper finds that beyond the problem of overlapping laws, weak institutional mechanisms and the need to check the arbitrariness of public officials as some of the problems that need to be addressed to build strong public-private partnership regimes in sub-Saharan Africa. The paper recommends among others, holistic strategies for strengthening the framework and practice in both countries and the need to make the public-private partnership process less cumbersome.
\end{abstract}

Keywords: public-private partnership, infrastructure, infrastructure funds, Nigeria, South Africa

\section{Introduction}

The huge costs associated with infrastructure funding as well as budget deficits can be regarded as the chief reasons for the adoption of the Public-Private Partnership (PPP) of infrastructure procurement (Arimoro A. , Public-private partnership and the right to property in Nigeria, 2019). Other reasons why policymakers opt for PPP include the need for the government to tap from private sector skill and expertise, the necessity for the public sector to concentrate on policymaking as well as the urgency to meet the increase in demand for infrastructure (Nwangwu, The legal framework for public-private partnerships (PPPs) in Nlgeria: Untangling the complex web, 2012) among others. Whilst there is no universal definition of the term 'PPP', most writers 
agree that it is a collaboration between the public authority and private sector entities to deliver infrastructure facilities (Arimoro A. , Public-private partnership and the right to property in Nigeria, 2019). It has been noted also that authors and institutions often define the term from their various viewpoints (Nwangwu, Public Private Partnerships in Nigeria, 2016).

It is important to differentiate between a PPP and other similar forms of procurement. A PPP is usually a long-term contract. It is not the same thing as privatisation where the government divests its interest in an enterprise. It is not a service or management contract as it involves the design and the building or rehabilitation of a public facility. In the context of the discussion in this paper, a PPP may be defined as 'any contractual or legal relationship between public and private entities aimed at improving and/or expanding infrastructure services, but excluding public works contracts' (Delmon, 2011, p.2). Also, there are at least four elements that should be present to identify a transaction between the public authority and the private sector as a PPP. These include - that it is a long-term contract, the existence of a project company responsible for the design of the facility, the private sector financial investment is repaid from revenues generated from the asset and a transfer of the facility back to the government at the end of the PPP contract (Yescombe, 2017).

Since Nigeria and South Africa are two of the largest economies in sub-Saharan Africa (Pham, 2017), a study of the impact of the introduction of the PPP model of infrastructure procurement is important, possibly serving as a guide for other economies on the continent. The success and advantages of adopting PPP in both countries could be beneficial in structuring PPP programmes in other sub-Saharan African economies. This is not to say that there have not been challenges or even outright project failures in both countries.

This paper examines the regulation of PPP in Nigeria and South Africa. In doing so, it needs to be pointed out that the aim of the paper is not to embark on a comprehensive analysis of the legal frameworks in both countries but to highlight on the areas of similarities and divergence, to investigate the practice under the various PPP laws and to suggest improvements in the practice in both territories. Previous works have dealt with the legal environment for PPP practice in both countries. For example, 
(Nwangwu, The legal framework for public-private partnerships (PPPs) in Nlgeria: Untangling the complex web, 2012), (Matey, 2019), (Arimoro A. , An appraisal of the framework for public private partnership in South Africa, 2018) and (Soyeju, 2013). The core themes covered in this paper include the establishment of an adequate legal framework, the institutional framework for PPP, ease of doing business, access to credit, stable and social environment, judicial review of decisions of the public-sector in commercial transactions and the principles of fairness and inclusivity. The above may be referred to as the indicators and drivers for success for PPP arrangement and execution. Since these parameters to a large extent, determine whether PPPs will succeed, it is important to analyse the structures both in Nigeria and South Africa to determine how policymakers can best design a successful PPP regime (Arimoro, 2018b).

\section{Need for an Adequate Legal Framework}

An independent, fair and efficient legal framework is a key to successful PPP project execution in any given jurisdiction (National Treasury, 2007). Given the very complex nature of PPP, the branch of the law that regulates it must be clear to both investors and practitioners (Smith, 2012). Significantly, Nigeria and South Africa operate three different levels of governance, with a different set of laws, in many cases, operating at the national and sub-national levels. Hence, it is important to know which laws apply at each level. In this section, the laws regulating PPP in both Nigeria and South Africa are discussed.

The enabling of a fair and transparent PPP legislation is a sine qua non for PPP success. However, it is worthy of note that common law countries like the United Kingdom and Australia have established PPP regimes through the use of policy statements and administrative document without enacting a dedicated PPP law (APMG International, 2017). This is may not be feasible in developing economies due to deficiencies in the development of public institutions. In emerging economies especially, PPP laws have been passed, especially where these laws were required to override existing laws that would have restricted the implementation of PPP projects (APMG International, 2017). In the case of Nigeria, for example, a PPP law is 
important to provide 'greater force, stability, transparency, and accountability' (APMG International, 2017 para 10).

\section{The Establishment of Nigeria's Public-Private Partnership Framework}

In Nigeria, federal legislators (made up of the Senate and House of Representatives) make laws at the national level. On the other hand, state lawmakers exercise the same powers at the state level. The Federal Republic of Nigeria is made up of a central government, a federal capital territory, 36 states and 768 local government areas. 1 The Constitution of the country assigns the responsibility (with certain restrictions) to each tier of government for infrastructural development within the territory over which it exercises control. Following this, there could be as many PPP laws and frameworks as there are different units of government. Indeed, some states of the federation including Cross Rivers, Ekiti, Lagos and Ogun have all established PPP frameworks with PPP units to oversee the administration of PPP in those states (Arimoro, 2018b).

The Nigerian federal government established a PPP framework to shed some of its responsibility for infrastructure development by increasing private sector participation in critical sectors of the Nigerian economy. This was to be done through privatisation and commercialisation of previously state-owned monopolies, especially in the telecoms and power sectors (Onuohia, et al., 2017). Before the government passed the Infrastructure Concession and Regulatory Commission (Establishment Etc) Act 2005 (ICRC 2005), the Nigerian government pursued a privatisation programme through which some state-owned enterprises were privatised. This process, which involved numerous transactions, including concessions, was consummated through the Bureau of Public Enterprises under the Public Enterprises (Privatisation and Commercialisation) Act No. 28 of 1999 (Nwangwu, Public Private Partnerships in Nigeria, 2016). Regrettably, however, the privatisation programme did not deliver expected results as it was marred by irregularities and the lack of technical and financial capacity on the part of the companies that acquired government interests in 
the now moribund monopolies. Further, most of the acquired companies have performed more poorly under new management than they were as public corporations (Arimoro, 2018b). It is not surprising therefore that there has been a shift from a privatisation drive to PPP (Nwangwu, Public Private Partnerships in Nigeria, 2016).

Quite notably, some PPP transactions were arranged under the Privatisation Act in Nigeria. This was even after the ICRCA 2005 had been passed (Nwangwu, Public Private Partnerships in Nigeria, 2016). Indeed, for a long time, it appeared as if the government of Nigeria 'could choose randomly between either of the two laws setting up PPP transactions as public authorities vacillated between either of the laws for different transactions' (Nwangwu, Public Private Partnerships in Nigeria, 2016, p. 28).

Given perennial budget deficits, the inefficient management of large infrastructure projects and services by the public authority, and the apparent failure of the privatisation programme, the Nigerian government's desire for a dynamic partnership with the private sector brought about a policy shift towards a PPP regime for the procurement of infrastructure (Onuohia, et al., 2017). In sum, the establishment of a legal framework for the administration of PPP in Nigeria is first, not unconnected with the failure of the privatisation initiative. Secondly, it is driven by the need to make the process for PPP procurement uniform and clear; and thirdly, it is occasioned by the necessity of providing some form of assurance to private investors that PPP contracts are binding (Arimoro, 2018b).

\section{Establishment of South Africa's Public-Private Partnership Framework}

Unlike Nigeria, where the failure of the privatisation agenda was the harbinger of PPP, the involvement of the private sector in the procurement of infrastructure in South Africa was based on the recognition that the private sector is better suited to provide effective services as well as the opportunity introduce private capital and expertise into state enterprises (Axis Consulting, 2013). South Africa's introduction of a PPP 
framework was hinged on the need to create an enabling environment for PPP success.

Having established the feasibility of the PPP model of procurement, in April 1997 the South African cabinet approved the appointment of an inter-departmental task force team to advance both legislation and policy to facilitate the adoption of a PPP framework. Subsequently, a PPP unit was set up under the National Treasury (Arimoro, 2018b). Following form this, a framework for PPPs was endorsed in December 1999, while the National Treasury issues regulations for PPPs in April 2000 (Axis Consulting, 2013).

Given South Africa's historical attachment for the importance of public procurement to the economic well-being of its citizens, all forms of procurement in the Republic, including PPP, are required to conform with accepted principles of fairness.2 While there is undoubtedly a need to heal the injustice of the past, it is opined that the procurement of infrastructure by the private sector should not be considered an area where there should be questions as to whether certain groups in the community are represented. This is irrespective of the principle of fairness that is core in the 1996 Constitution and where is enshrined in the preamble to the Constitution (Arimoro, 2018b). The reason for this submission is that the requirement to be fair to all communities tends to stifle private-sector competition. Again, private sector consortia who feel obliged to meet such targets often resort to malpractices to conform to their burdensome requirements.

\section{Similarities between the Legal Frameworks for PPP in Nigeria and South Africa}

In this subsection of the paper, the focus is on the similarities between the frameworks for PPP in Nigeria and South Africa. The key points for consideration are the tiers of government, the establishment of regulatory units for PPP, the standards required for

21996 Constitution of the Republic of South Africa, section 217 states that 'When an organ of state contracts for goods or services, it must do so in accordance with a system which is fair, equitable, transparent, competitive and cost-effective.' 
PPP procurement, the emphasis on value for money (VfM) as a key driver for PPP, as well as advancing PPP as a tool to ensure balanced regional development.

The government in South Africa is constituted at national, provincial and local spheres, which are distinctive yet interdependent and interrelated. 3 In Nigeria, the government is constituted at the federal, state and local government levels. Remarkably, there are distinct frameworks for the regulation of PPP at the national and sub-national levels in both countries.

To ensure the efficient regulation and monitoring of PPP projects, the Nigerian Infrastructure Concession and Regulatory Commission (Establishment Etc.) Act 2005 set up the Infrastructure Concession Regulatory Commission (ICRC) as the main regulatory institution for PPP at the federal level in the country. In South Africa, a PPP unit established in 2000 under National Treasury is charged with the responsibility for regulating PPPs. Notably, both Nigeria's ICRC and South Africa's National Treasury PPP Unit play vital roles in the arrangement of PPPs. In both countries, the initiative to start up a PPP project lies with the ministry, department or agency of government (MDA) or institution responsible for the project (Arimoro, 2018b). In both jurisdictions, it is safe to say that the rationale for having dedicated PPP units is based on the reasoning that the MDA may not fully appreciate the budgetary implications of PPPs due to their off-budget nature (Burger, 2006).

Furthermore, while under section 20 of Nigeria's ICRCA 2005, the ICRC takes custody of every concession agreement and monitors compliance, the function of the South African PPP Unit is to ensure that all agreements comply with the legal requirements of affordability, value for money and risk transfer (Burger, 2006). It needs to be observed that merely stating that the ICRC is to ensure compliance fails to specify what standards should be complied with. The function of ensuring compliance is clearly defined in South Africa but not in Nigeria, even though the ICRC maintains that is is driven by certain key principles i.e. VfM, risk allocation, public interest, output requirements, transparency, competition and capacity to deliver (Arimoro, 2018b). Consequently, this writer argues that in future amendments of the ICRC 2005 in 
Nigeria, the parameters with which contracts should comply must be clearly defined for the sake of uniformity and to make the job of the ICRC easier. Interestingly while the World Bank rates the South African PPP environment as strong, with a solid track record in delivering major projects because of an active and efficient PPP unit (The World Bank, 2016), Nigeria's equivalent, the ICRC, us still learning the ropes. Fundamentally, the ICRC appears to lack the powers of a regulator in the event of failure by MDAs to adhere to contractual terms.

The standards for PPP procurement in both jurisdictions are quite similar. Nigeria and South Africa, in line with international best practice, regard VfM outcome as a key consideration for PPP projects. In other words, for a project to be procured as a PPP, it must be evident that it is cheaper to do so via traditional procurement (Axis Consulting, 2013).

In South Africa, PPPs are considered a tool for Black Economic Empowerment (BEE),4 requiring the formation of private consortia in the form of special purpose vehicle (SPVs) This is intended to facilitate long-term beneficial partnerships between new black-enterprises and experienced, resourced companies, both as equity partners and in project management, and both at the private party SPV and subcontracting levels. Invoking a similar rationale, Nigeria considers PPP as a tool to ensure balanced regional development.5 Taking into consideration South Africa's history of apartheid and Nigeria's nuanced history of the ethnic and regional marginalisation of various sections of the country at different times, it is not surprising that government in both countries consider PPP as a 'political tool' to right societal wrongs. Thus, in South Africa, it is expected that the previously marginalised black population will be given opportunities in the procurement of PPP projects. In Nigeria, since an equitable distribution of government facilities across the geo-political zones in the country is deemed ideal, there is an assumption that in PPP procurement, as much as possible, all sections of the community must be catered to. In the opinion of this writer, using PPP as a political tool raises the level of political risks associated with any project concerned. This will make PPPs less attractive to private investors. 


\section{Areas of Divergence}

In this subsection, the main areas of divergence between the frameworks in Nigeria and South Africa are discussed. The area with notable differences includes the origin of the main legislation for PPP, the scope of application of the PPP laws in both jurisdictions, and the key stages in the PPP life cycle in Nigeria and South Africa.

While Nigeria has a principal law passed in 2005 to regulate PPP transactions, South Africa does not have one. Instead, the National Treasury issued Regulation 16 in 2004 pursuant to the Public Finance Management Act. It seems a paradox that the main law for PPP is a product of the legislature in Nigeria whereas the regulation for PPP in South Africa is the product of a public agency. But while an investor or anyone interested in PPP in Nigeria must consult a web of laws including the main PPP law to get a grasp of the regulatory environment for PPP, a similar exercise in South Africa is less cumbersome. It is, therefore, safe to say, in the opinion of this writer, PPP is over-regulated in Nigeria.

Another area of divergence is that at the national and sub-regional levels in Nigeria, different PPP laws apply. The ICRCA 2005, which is an Act of the National Assembly, is the applicable law for PPP where there is a partnership involving any federal MDAs and the private sector. At the subnational level, states that wish to introduce the PPP model must establish their own local PPP framework.6 The case in South Africa is quite different, as the same laws and regulations apply to both the national and provincial governments. Municipal authorities are an exception since they are guided by the Municipal Finance Management Act No. 56 of 2003. Further, it is worthy of note that the federal PPP law in Nigeria does not make provision for the private finance initiative (PFI) model of PPP, thus restricting PPPs at the national level to concessions. However, the PPP law in Rivers State allows for PFI styled PPPs. The current South African framework, on the other hand, appears not to allow the various provinces to cater to their unique needs.

${ }_{6}$ On account of the country's federal constitution. 
In Nigeria, any state implementing a PPP regime must establish its independent PPP unit to manage PPPs in that state. This is because the ICRC is responsible for PPP at the federal level only. On the other hand, even though South Africa has only nine provinces and a national government, a single PPP unit regulates all PPPs in the country. The weakness with this is that it does not allow for the development of PPP expertise at the second-tier level of government.

Finally, there is a key difference in the number of stages in the PPP project cycle. In Nigeria, the ICRC, in consonance with international best practice has identified four phases: project development and appraisal; project procurement; project implementation; and project maturity (Infrastructure Concession Commission, 2017). In practice, though, in the case of a solicited PPP procurement, the process unfolds over 12 stages. It is submitted that this arrangement is cumbersome and not good for business. Streamlining the process into six stages would be appropriate. In South Africa, the PPP project cycle as provided for in Modules 3,4,5 and 6 of the PublicPrivate Partnership Manual issued by the National Treasury PPP Unit in terms of the Public Finance Management Act - is more attractive to an investor as it merely restates the four phases in a PPP life cycle in clearer terms. Placed side by side, a prospective investor is more likely to choose to invest in a PPP project in South Africa than in Nigeria because of the clarity and straightforwardness of the PPP process in South Africa.

\section{The Institutional Framework}

Apart from entrenching a legal framework for the administrating and regulating PPP, it is imperative that an institutional framework is put in place to ensure that the processes of initiation, administration, control and accountability regarding PPP projects match international best practice (Arimoro, 2018b). A strong and effective regulatory regime is necessary to attract large-scale private sector investment. The institutional arrangements in most countries include primarily the PPP unit and the MDAs that are relevant to the procurement and execution of the PPP project (Arimoro, 2018b). Where investors have the perception that the institutions charged with the responsibility for initiating or superintending the project and its outcome are not strong enough or are inconsistent, the chances of the private sector participating in PPP 
execution and delivery are very slim. The criteria for appointing the heads or members of MDAs directly responsible for PPP delivery must be based strictly upon expertise, experience and the ability to deliver. This is a major challenge for a country like Nigeria burdened by a 'federal character' principle which requires that:

The composition of the Government of the Federation or any of its agencies and the conduct of its affairs shall be carried out in such a manner to reflect the federal character of Nigeria and the need to promote national unity, and also to command national loyalty and thereby ensuring that there shall be no predominance of persons from a few states or from a few ethnic or other sectional groups in that government or any of its agencies.

The implication the above principle is that some of those responsible for managing PPPs or making key decisions regarding them may lack expertise or experience, and are in their positions by virtue of an employment quota. Their lack of expertise and makes them error-prone. Over time, the institutions they manage become weakened. Therefore, to spur economic growth, the federal character principle should be relaxed for key institutions critical to Nigeria's economy.

\section{Nigeria's Institutional Framework for Public-Private Partnership}

The National Policy on Public-Private Partnership states as follows:

The Government will create an institutional framework that will reinforce the accountability of Ministries, Departments and Agencies (MDAs) of the Federal Government for the delivery of public services within their areas of responsibility, whilst ensuring that they have access to appropriate guidance, training, expertise and resources to plan, procure and manage investment projects and public services efficiently and effectively taking into account value for money and long-term affordability. It will issue guidance for the benefit of those states that propose to develop their own PPP policies and programmes, and will set up mechanisms to coordinate these and encourage the development of standardised documents where appropriate. 
It will coordinate communication between the public authorities across the Federation and private sector contractors.7

It is hard to say that the goals mentioned above have been achieved in Nigeria. This is due to the lack of synergy between government agencies and the ICRC (Arimoro, 2018b). The ICRC is not considered as a strong regulator (Nwangwu, Public Private Partnerships in Nigeria, 2016) compared to other regulatory agencies in the country like the Nigerian Broadcasting Commission (NBC) or the Nigerian Communications Commission, who are capable of imposing sanctions even on public establishments to mention a few examples. While the NBC, for instance, can sanction an erring government-owned TV or radio station for an offensive broadcast, the ICRC is like the proverbial dog that does not bark, let alone bite. This weakness explains why the Federal Airports Authority (FAAN), for instance, is reneging on its contractual obligations to its PPP partner, Bi-Courtney Aviation Services Ltd, to enforce the use of the Murtala Mohammed Airport Terminal II by local flights landing in Lagos. The ICRC failed in its responsibility as a regulator to enforce compliance, prompting the concessionaire to go to court to enforce that clause in the PPP contract (Arimoro, 2018b).

As presently constituted, the institutional framework for PPP in Nigeria is, in the opinion of this writer, akin to having too many cooks preparing a pot of broth (Arimoro, 2019b). Apart from the ICRC, the primary institution for the administration and control of PPP at the national level, there are several other MDAs including the National Planning Commission (NPC), the MDA initiating the project, the Federal Ministry of Finance, the Debt Management Office, the Office of the Accountant General of the Federation, the Bureau of Public Procurement and the Bureau of Public Enterprises are some of the other bodies that play a role in PPP regulation in the country. Unfortunately, having several players for PPP in Nigeria creates unnecessary bureaucratic bottlenecks.

\section{South Africa's Institutional Framework for Public-Private Partnership}


Compared to Nigeria's, South Africa's institutional framework for PPP is much more compact. Consequently, the process for the approval and execution of PPP projects in South Africa is less complex than in Nigeria. The same National Treasury provides the various treasury approvals for both national and provincial PPP projects (Axis Consulting, 2013). Where there is a need to offer guarantees or indemnities, the Ministry of Finance is required to authorise any such transaction.8 By implication, if there is no need for the issue of guarantee or indemnity by the public authority there is no need for such approval by the Ministry of Finance. This arrangement helps to expedite projects, unlike the Nigerian case where all national PPP projects must at one point or another have the approval of the Federal Ministry of Finance.

A unique arrangement in South Africa is the location of the PPP Unit within the National Treasury. The same PPP Unit assists National Departments and Provincial Governments with PPPs. The unit is made up of 17 professional staff who are allocated projects depending on individual sector expertise and interest. Even though the current structure is designed to enable efficiency and speed, the South African PPP Unit can be very easily be overstretched and overburdened. And while the institutional leanness is less cumbersome, the centralisation of the PPP Unit in a large country like South Africa could stifle the development of PPP expertise. It seems reasonable to conclude that the creation of provincial units for PPP across the country would provide room for the development of experts and help strengthen the PPP regime in South Africa.

\section{Ease of Doing Business}

A favourable economic environment is a prerequisite for a successful PPP regime (Delmon, 2011). Since PPPs involve the participation of the private sector, the ease with which business can be initiated and carried on in any given jurisdiction is often a key consideration for prospective foreign investors wanting to determine whether it makes business sense to embark on a venture especially that involves the public sector. The World Bank Survey on the Ease of Doing Business covers 11 areas of 
business regulation - starting a business, dealing with construction permits, getting electricity, registering property, getting credit, protecting minority investors, paying taxes, trading across borders, enforcing contracts, resolving insolvency and some aspects of the labour laws (Africapedia, 2017). The Ease of Doing Business Report is a guide for investors and, as such, is one of the documents prospective PPP investors consider before making investments in any country.

No doubt enhanced ease of doing business in any country creates the needed stimulus for economic recovery and sustainable growth. In the light of the light recent economic challenges in both Nigeria and South Africa, improving the ease of doing business in both countries is bound to be impactful. It follows therefore that the governments in both countries need to take a holistic approach to introduce reforms geared towards removing trade barriers.

\section{Ease of Doing Business in Nigeria in Relation to PPP}

Nigeria is ranked as a lower-middle-income country. Nigeria has improved from its (2017) 169th position out of 189 countries in the World Bank Ease of Doing Business rankings to 131 among 190 economies in 2019 (Trading Economics, 2019). It is worthy of note that the administration of President Muhammadu Buhari in July 2016 established the Presidential Enabling Business Environment Council (PEBEC), with a mandate to remove bureaucratic and regulatory constraints to doing business in Nigeria (Vanguard, 2017). Even though the PEBEC is chaired by the Vice President, Prof Yemi Osinbajo, it is the opinion of this writer that significant changes will not be experienced without the commitment of public servants who are usually in charge of the day-to-day administration of the various institutions in the country with a mandate to ensure that specific targets are met. In addition to simplifying the regulatory framework, steps must be taken to introduce market-friendly policies and, importantly, a re-orientation of the civil service. Indeed, even a simplified regulatory framework with the same public servants would be akin to putting new wine in old wine bottles, as civil servants in Nigeria are notorious for making simple processes complex. 
It is further submitted that the incentives provided by the federal government of Nigeria in the agricultural,9 energy 10 and power11 sectors, as well as the incentives available for foreign capital contribution, are very useful and must be sustained. However, the federal government must make the repatriation of profits and capital by foreign investors easier, as this is one area that has been challenging for business with foreign participation since the President Buhari assumed office as President in 2015. The situation has not been helped by lower crude oil earnings that have led to a scarcity of foreign exchange.

\section{Ease of Doing Business in South Africa in relation to PPP}

The World Bank ranks South Africa as an upper-middle-income economy. South Africa is an African economic powerhouse with a rich cultural diversity. In the World Bank's Ease of Doing Business Report for 2019, the country moved down from its 74th position in 2017 to 84 in 2019 (Trading Economics, 2019b). South Africa is highly ranked protection of investors, for getting credit and for the ease with which construction permits can be obtained. It needs to improve in the areas of registration of properties and access to electricity. It takes about 226 days to get electricity in South Africa. It is worrisome that it may take Eskom, the public utility company, about 60 days to provide an estimate after an application has been received, and another 165 days to complete external connection works (The World Bank, 2017).

The previous administration of President Jacob Zuma launched the 'One Stop Shop' to improve the ease of doing business in South Africa, signalling the country's intention to improve its efforts to attract direct investment and new business (CGTN Africa, 2017). It is expected that this initiative will impact on South Africa's attractiveness to foreign investors, especially those with a bias toward investments in infrastructure as an alternative to traditional investment instruments.

\footnotetext{
9 VAT exemption on tractors and zero restriction on capital allowance claimable for companies in the agroallied businesses.

10 Tax free period of three years which may be renewed for a further two years, or 35\% investment allowance. 11 Exemption from VAT on plant and equipment acquired to generate electricity; exemption from import duties on plant and equipment imported to generate electricity through the utilisation of Nigerian gas.
} 
It is worth pointing out that South Africa presents some challenges for the foreign investor. To the complex business culture in the country, one must add the ripple effects of xenophobia. These could scare off expatriates since investors often have compatriots in communities where they have their investments. It is therefore submitted that South Africa must proactively deal with the challenge of xenophobia in the country. The delay in accessing electricity also needs to be addressed to improve on the country's performance on the doing business index.

\section{Access to Credit for PPPs}

Infrastructure finance is usually characterised by large-upfront capital outlay during the construction phase, with relatively smaller operational costs (Turley \& Semple, 2013). As a corollary, investors approach lenders to help finance PPP projects. Over time, PPPs have developed a distinctive form of credit financing referred to as project finance (Barner, 2019). Credit risk is, therefore, a key element in PPP contracts, and deed is significant in the structuring of PPP finance. This is in line with the basic investment tenet of a positive correlation between risk and the cost of finance, such that the more the risk a lender is expected to take, the higher the required rate of return on the investment. In this regard, the public sector must ensure that a project is best tackled as a PPP before selecting that option. This is because a government may obtain funds cheaply than a private sector concern since the government is regarded as a low-risk borrower (Barner, 2019). Due to the huge capital outlay involved, funding for a PPP project is typically acquired from various sources, which may be a combination of equity and debt (The World Bank, 2019).

The project sponsors are the investors in the project company or consortium. They make available the expertise and some of the services rendered by the project company such as construction or operations. The kind of funding that sponsors provide is usually referred to as equity. These are contributions in the form of shares. In practice, equity funding is the lowest in the order of priority of funding contributions to a project. Thus, other contributors, especially lenders, have the right to project assets and revenues before equity contributors receive any return or, on termination or insolvency, any repayment. Hence, equity contributors are the highest risk-takers (The World Bank, 2019). 


\section{Access to Credit for PPP in Nigeria}

As of 2017, Nigeria was ranked 44 out of 190 economies in terms of the ease of getting credit (The World Bank, 2017). However, since PPPs are long-term investments usually spanning 20 to 30 years, and because the financial market in Nigeria is still evolving, obtaining credit for PPP projects is extremely challenging for promoters. It is therefore important to highlight the options for PPP projects in Nigeria.

A primary channel of finance for a PPP project is equity. Promoters of the project - the consortium- usually set aside their equity for the project company. This type of funding is not difficult to raise within the country, given the experience of project companies like Bi-Courtney Aviation Services Ltd, Lekki Toll Concession Company Ltd, BiCourtney Highway Services Ltd, to mention a few (Arimoro, 2018b).

As a mono-economy, Nigeria is burdened by a weak financial sector, with lenders preferring the attractions of the oil industry. Even though the World Bank views Nigeria as one the promising pipelines for PPP projects in Africa, given the support for the use of PPP in the development of infrastructure in Nigeria's recent budgets (The World Bank, 2017), local financing from the country's commercial banks for long-term infrastructure is hard to come by (Chima, 2016). The argument is that few projects in the country are bankable and that the preparation process for PPP in the country is not yet sophisticated enough to address bankability issues, making it difficult to access credit (Detail Solicitors, 2009). However, this writer's view is that since PPP is a new phenomenon in Nigeria, the waters are still being tested, with lenders preferring lending to sectors that have gained their trust over the years. Naturally, as success is achieved in the arrangement, execution and operation of PPP projects in the country, this trust will in due course be earned. Typically, the need for debt financing for infrastructure projects is substantially greater than equity. Debt servicing in Nigeria is customarily provided by commercial banks with relative short tenure.

A second funding option being explored for PPPs in Nigeria is tailor-made infrastructure funds. Infrastructure funds are considered alternative investment instruments to traditional investments in equities and the money market. A period of 
economic depression followed the global financial crisis, resulting in foreign investors recalling investments in the Nigerian capital market in the late 2000s. Coupled with the volatile nature of the stock market, this crisis led investors to show more interest in alternative, less unpredictable investments like Infrastructure Funds (IFs). In recognition of the massive opportunities for IFs, Nigeria's Security and Exchange Commission (SEC) issued the Rules on Infrastructure Funds to guide to fund managers and Infrastructure Capital Companies. The Rule 1 of the SEC Rules on Infrastructure Funds define 'infrastructure fund' to be a specialised fund or scheme that invests primarily (minimum 90\% of the scheme's net assets) in the securities or securities debt instrument of a specified range of companies, namely, infrastructure companies, infrastructure capital companies, infrastructure projects, special purpose vehicles which are created for facilitating or promoting investment in infrastructure, and other permissible assets, including the revenue-generating projects of infrastructure companies or the projects of special purpose vehicles (SPVs).

Under the SEC Rules, an IF may only be registered with the SEC when the fund manager has a minimum of two key personnel having experience in the infrastructure sector (Rule 3 SEC Rules on IFs). Merely having experience in the infrastructure sector is too wide a definition. The Rules should provide that at least two personnel must be experienced in infrastructure finance in the terms that define their level of experience.

The fund may be an open or a close-ended scheme with a minimum tenure of seven years, or an interval scheme with a lock-in period of five years and an interval period not longer than one month, as may be specified in the scheme of information document. Furthermore, the indicative portfolio of the fund must be disclosed to its potential investors stating the type of assets the fund would invest in (Rule 4SEC Rules on IFs). It is pertinent to note that the introduction of infrastructure funds has helped to widen the scope of opportunities for investment in Nigeria. Regrettably, however, fund managers in Nigeria who offer investment in infrastructure funds target only high net-worth (HNI) clients. The entry threshold to subscribe to any of the funds makes it impracticable for most of the population, bearing in mind that Nigeria is a lower-middleincome country. Two prominent infrastructure funds are the Chapel Hill Nigeria Infrastructure Debt Fund denominated in Naira and managed by Chapel Hill Denham 
Management Ltd, and the ARM Harith Fund, which was incorporated in 2013 with total commitments of approximately US $\$ 91$ million. The Fund is an investor in the US $\$ 876$ million 450MW Azura-Edo independent power plant currently under construction in the country (ARM-Harith, 2017). Infrastructure funds provide investment opportunities to investors as well as funding for PPP projects. In the view of this writer, the SEC should require fund managers to set an investment threshold that makes it feasible for lowmiddle income earners in the country to invest in infrastructure funds.

In 2017, the federal government of Nigeria introduced the Sukuk bond. Sukuk is an Islamic finance instrument designed to finance large-scale infrastructure projects. Investors in the fund receive income based on the assets rather than interest on conventional bonds (Oniha, 2017).

Another area of significant interest for infrastructure financing in the country is the pension fund assets managed by Pension Fund Administrators (PFAs). Although the Pension Reform Act 2014 does not specifically name infrastructure as an area for investing pension fund assets, section of 86 of the Act is sufficiently broadly worded to include infrastructure financing. It is submitted that steps must be taken to ensure the safety of pension assets and to gain the support of the Nigerian workers who are sceptical about the safety of such in investments. It is submitted that several steps must be taken by policymakers to ensure a healthy environment for the investment of pension assets in infrastructure. First, the viability and bankability of a project must be established before a PPP option is chosen for that project. This implies that PPP projects must not be pursued simply based on the federal character principle. Secondly, a full repayment guarantee on the part of government will provide PFAs with the necessary confidence; and thirdly, the government must address the fears of pension fund contributors and the labour unions about the safety of pension fund assets invested in infrastructure funds.

\section{Access to Credit for PPP in South Africa and Lessons for Nigeria}

South Africa's financial market is much more developed than Nigeria's. For example, Treasury Regulation 16 is not prescriptive about the financing of a PPP in South Africa (Arimoro, 2018b). Hence the assumption is that the method of financing a project varies from project to project and sector to sector. Furthermore, the South African 
market has a wider range of products and instruments available for investors interested in funding infrastructure.

The options available for funding infrastructure, such as equity provided by the promoters of the project, and debt financing such as bonds and credit from commercial banks, are similar to those in Nigeria, discussed above. In this section, the focus rests rather upon South African pension funds and infrastructure funds in the provision of credit to PPP. This focus should be seen in the light of a template that might be followed by policymakers in Nigeria since this is one area where the financial market is still evolving in that country.

Pension funds in South Africa demonstrate the huge potential of pension funds to drive economic growth (Moleko, 2017). In 2014, South Africa's Eskom Pension and Provident Fund (EPPF) invested $\$ 30$ million in infrastructure projects through private equity house Abraaj, based in Dubai, as well as in mobile phone infrastructure through London's Helios (Minney, 2017). The diversification of pension fund assets demonstrated in these South African investments should be explored by the pension industry in Nigeria. There must be a balance between being too cautious and not generating enough returns for pension fund members and taking a moderate risk to generate greater returns, considering that returns are often proportionate to risk. The current cautious approach by PFAs, as dictated by Nigeria's PENCOM, is influenced by the need to ensure the safety of RSA holders' funds but may not be ideal if fund growth is considered important. It is therefore submitted that a middle-ground approach is adopted, with the right risk assessment measures put in place to ensure that pension fund members receive better returns on their investments. This will involve the use of funds and investment management experts with experience in producing competitive returns while ensuring fund safety.

Because of its well-developed financial market, compared to its peers in Africa, South Africa has a wide range of infrastructure funds to choose from. For example, the South Africa Infrastructure Fund (SAIF) with a fund size of over $\$ 1,855$ million. The first 20year infrastructure fund in South Africa, it matured in June 2016. The Fund invested in several projects within and beyond South Africa, as follows: the Bakwena Platinum Corridor Concession, with a $62 \%$ indirect interest in the $385 \mathrm{~km}$ toll road; the N3 Toll 
Concession (38\%); ICO Global Communications Holdings (1\%); Ucingo Trust (38\% in the $415 \mathrm{~km}$ toll road); Trans African Concessions, South Africa and Mozambique (50\% interest in $570 \mathrm{~km}$ toll road); and the African Portland Holdings Mozambique and Namibia (34\% interest in port and logistics terminals), among others (Africa Infrastructure Investment Managers, 2017). Upon the maturation of the Fund, the managers, African Infrastructure Investment Managers (AlIM), announced the successful sale of investments in three privately-concessioned toll roads in South Africa. The transactions were successfully concluded on 4 July 2016. The sale is the largest private equity realisation for toll road infrastructure in Africa (Africa Infrastructure Investment Managers, 2017). According to Jurie Swart, the CEO of AlIM, the sale transaction demonstrates the increasing development of the African infrastructure sector and addresses the concern investors may have around the ability to dispose of infrastructure assets (Southern Africa Venture Capital and Private Equity Association, 2016). The success of the liquidation of the SAIF fund is a lesson for Nigeria's policymakers, fund managers as well as private and institutional investors, in the sense that it provides a workable template for similar funds in South Africa, Nigeria and elsewhere on the continent. With the involvement of experts and other fundamentals in place, infrastructure funds can help to grow the economy as well as ensure that funds are safely invested and paid back to investors at maturity.

\section{Judicial Review of Decisions of the Public Sector in Commercial Transactions}

One area that is of concern to private investors is the need to check the arbitrary powers of governments when they deal with private parties. This is because the public sector is always the dominant party in all PPP relationships. Judicial review is the power of the court to serve as a deterrent to cases to public officials abusing their powers (Ogbuabor, 2011-12). In Abdulkarim v In Car Nigeria Ltd,12 the Supreme Court of Nigeria per Nnaemeka-Agu, JSC (as he then was) described the functions of the court as far as judicial review is concerned. These include the need to ensure that every arm of government plays its role in the spirit of the separation of powers and accordance with the rule of law. In South Africa, there is a clear Constitutional provision in favour of good governance in administration and this includes where the 
public authority enters into contractual agreements with the private sector.13 Thus, an aggrieved private investor or project company can challenge the action of the public authority in a court. Investors must know that they can pursue a cause of action in court in both Nigeria and South Africa to overturn a wrongful action by a public official.

\section{Conclusion}

The regulatory and administrative environments for the success of PPP projects in Nigeria and South Africa have been the focus of this paper. A key finding from the paper is that Nigeria is still going through a discovery phase in so far as PPP is concerned, while the environment in South Africa is comparatively advanced. While this paper does not delve in the realm of describing how the legal framework in both frameworks operates, the paper rather highlights areas where both countries can learn from each other to improve on their local practice for PPP. The themes examined above are the divers that can lead to successful outcomes for PPP in the sub-Saharan African context. It is clear from the discussion above that while South Africa offers a template for other economies in sub-Saharan Africa to learn from, the Nigerian situation is a clear case of the lessons to be learnt on the journey to achieve maturity in structuring PPPs.

The findings of the paper suggest that it is imperative that Nigeria further develops its financial market, strengthen its institutional framework for PPP and put in measures to make the PPP process less complex than it already is. To make the environment attractive for PPP investors, Nigeria needs to strengthen its resolve to check the excessive powers of public officials as this can discourage private investors.

For both Nigeria and South Africa, transparency in the award of PPP contacts, adherence to contractual terms by the public authority and the private sector party as well as efficient regulatory mechanisms are essential ingredients for PPP success. 


\section{Bibliography}

Africa Infrastructure Investment Managers. (2017). South Africa Infrastructure Fund. Retrieved October 27, 2017, from https://aiimafrica.com/funds/funds_saif/ Africapedia. (2017). Africa in the doing of business rankings 2017. Retrieved October 23, 2017, from http://www. africapedia.com/2016/11/02/doing-business-africa/ APMG International. (2017). Legal and administrative approaches to establishing PPP frameworks. Retrieved June 1, 2017, from https://pppcertification.com/ppp-certification-guide/152-legal-and-administrativeapproaches-establishing-ppp-frameworks

Arimoro, A. (2018). An appraisal of the framework for public private partnership in South Africa. European Procurement and Public Private Partnership Law Review, 13(3), 214 -228.

Arimoro, A. (2019). Public-private partnership and the right to property in Nigeria. African Human Rights Law Journal, 19(2), 763-778.

Arimoro, A. E. (2018). The role of law in the successful completion of public-private partnerships in Nigeria: Lessons from South Africa. Cape Town, South Africa: PhD Thesis University of Cape Town.

Arimoro, A. E. (2019). Institutional framework for public-private partnerh?ships in Nigeria: Is it a case of too many cooks for one pot of brot. Business Law Review, 40(2), 73-79.

ARM-Harith. (2017). Who we are. Retrieved October 27, 2017, from http://armharith.com.ng/about/

Axis Consulting. (2013). PPP country paper: South Africa. Retrieved October 13, 2017, from http://www.sadcpppnetwork.org/wpcontent/uploads/2015/02/south_africa_27012014.pdf

Barner, B. (2019). Project finance. Black's Law Dictionary.

Burger, P. (2006). The dedicated PPP unit of the South African National Treasury. Agencies and Public-Private Partnerships. Madrid: OECD.

CGTN Africa. (2017, March 17). One stop shop to improve doing business launched in South Africa. Retrieved June 2020, from CGTN Africa: https://www.youtube.com/watch?v=VV1GJsI9cKU

Chima, O. (2016, May 11). Nigeria; Adopting the public private partnership model. This Day. 
Delmon, J. (2011). Public-Private Partnershp Projects in Infrastructure: An Essential Guide for Policy Makers. Cambridge: Cambridge University Press.

Detail Solicitors. (2009). Securing finance for infrastructure development (public private partnership) projects in Nigeria. Retrieved October 27, 2017, from http://www.detailsolicitors.com/index.php?section=news\&cmd=details\&newsid $=2 \&$ printview $=1 \&$ pdfview $=1$

Infrastructure Concession Commission. (2017). PPP Life Cycle. Retrieved June 23, 2019, from http://www.icrc.gov.ng/ppp/

Matey, R. (2019). A comparison of public-private partnerships in Nigeria and South Africa. Washington University Global Studies Law Review, 18(3), 691-722.

Minney, T. (2017, January 25). The power of pension funds for African infrastructure. African Business Magagzine.

Moleko, N. (2017, July 25). SA's pension funds grow national savings rate flounders. Financial Mail.

National Treasury. (2007). Public Private Partnership Manual. Retrieved October 5, 2017, from

http://www.ppp.gov.za/Legal\%20Aspects/PPP\%20Manual/Module\%2001.pdf

Nwangwu, G. (2012). The legal framework for public-private partnerships (PPPs) in

Nigeria: Untangling the complex web. European Procurement and Public

Private Partnership Law Review, 7(4), 268-277.

Nwangwu, G. (2016). Public Private Partnerships in Nigeria. London, United Kingdom: Springer Nature.

Ogbuabor, C. (2011-12). Expandin the frontiers of judicial review in Nigeria: The gathering storm. Nigerian Juridical Review, 10, 1.

Oniha, P. (2017, September 18). The case of Nigerian sukuk. This Day.

Onuohia, F., Okoro, O. J., \& Mimiko, B. (2017). Nigeria. In The Public-Private Partnership Law Review (pp. 157-166). London: Law Business Research Ltd.

Pham, P. (2017). Africa's economic prospects in 2017: Ten countries to watch.

Retrieved June 23, 2020, from Atlantic Council:

https://www.atlanticcouncil.org/blogs/africasource/africa-s-economicprospects-in-2017-ten-countries-to-watch/

Smith, A. (2012). Policy, legal and regulatory frameworks for successful PPPs. Retrieved October 5, 2017, from 
https://www.unescap.org/sites/default/files/4a-Policy-legal-regulatoryframeworks.pdf

Southern Africa venture Capital and Private Equity Association. (2016, July 5). Press release: South Africa's first dedicated infrastructure equity fund achieves successful sale of toll road assets. AlIIM.

Soyeju, O. (2013). Legal framework for public private partnership in Nigeria. De Jure, 34, 814-832.

The World Bank. (2016). South Africa. Retrieved June 24, 2020, from https://pppknowledgelab.org/countries/south-africa

The World Bank. (2017). Ease of doing business 2017: Economy profile of South Africa. Washington DC: The World Bank.

The World Bank. (2017). PPP knowledge lab: Nigeria. Retrieved June 25, 2020, from https://pppknowledgelab.org/countries/nigeria

The World Bank. (2019). Sources of financing and intercreditor agreement.

Retrieved June 25, 2020, from https://ppp.worldbank.org/public-privatepartnership/financing/sources

Trading Economics. (2019). Ease of doing business in Nigeria. Retrieved June 24, 2020, from https://tradingeconomics.com/nigeria/ease-of-doing-business Trading Economics. (2019). Ease of doing business in South Africa. Retrieved June 24, 2020, from https://tradingeconomics.com/south-africa/ease-of-doingbusiness

Turley, L., \& Semple, A. (2013). Financing sustainable public-private partnerships. International Institute for Sustainable Development Briefing Note , 3, 3.

Vanguard. (2017, August 24). Ease of doing business: FG moves to improve ranking. Vanguard.

Yescombe, E. R. (2017). Public-Private Partnerships in Sub-Saharan Africa. Dar es Salaam, Tanzania: UONGOZI Institute. 